\title{
IMPLEMENTASI PRINSIP-PRINSIP \\ BUDAYA KERJA APARATUR DI LINGKUNGAN \\ PEMERINTAH DAERAH DI KALIMANTAN ${ }^{19}$
}

\author{
Oleh: Siti Zakiyah, S.Si ${ }^{20}$
}

\begin{abstract}
Empirical phenomena show that public accountability and government performance is moderately weak. In that sense, the superlative accomplishment of the state bureaucracy in implementing its task and responsibilities depends not only on the intellectual and managerial capacity, but also on the behavior and organizational culture. This implies that capacity building process has to embrace effort of constructing knowledge and skills as well as good attitude, evenly. In order to strengthen the dimension of work culture in a government institution, State Minister for Apparatus Empowerment (MENPAN) has released many policies, particularly Decree No. 25/KEP/M.PAN/4/2002 concerning Guidance of Extending Work Culture for State Apparatus, from which this paper identifies the current condition and analyses the implementation of work culture principles in the local government institutions in Kalimantan region.
\end{abstract}

Keywords: budaya kerja, aparatur daerah, Kalimantan.

\section{Pendahuluan}

Semenjak lebih dari satu abad yang lalu, birokrasi di seluruh belahan dunia telah memiliki stigma yang negatif. Hal ini nampak dari pernyataan Kanselir Jerman periode 18701890, Otto von Bismarck, pada tahun 1891 bahwa "birokrasi adalah apa yang mendatangkan kesengsaraan bagi kita”. Keluhan-keluhan tentang inefisiensi, pelayanan yang lambat, biaya siluman, sampai KKN sudah menjadi rahasia umum. Pada skala yang lebih makro dapat dilihat fenomena-fenomena berupa tingginya indeks korupsi versi Transparency International, survey pada bulan Oktober 2005 menempatkan Indonesia di posisi ke-enam terkorup diantara 158 negara, atau country risk indeks tingkat risiko) Indonesia yang berada pada posisi ke-150, dari 185 negara yang disurvei. Dari aspek pembangunan SDM, Human Development Report 2003 yang dipublikasikan oleh UNDP melaporkan bahwa dari 173 negara di dunia, Indonesia ternyata berada di posisi 110, di bawah Philipina, Cina, dan bahkan Vietnam. Selain itu, World Investment Report WIR) 2003 membuat peringkat indeks kinerja Foreign Direct Investment FDI) 1999-2000, diantara 140 negara, Indonesia ternyata menempati urutan ke-138, dua di bawahnya adalah Gabon dan Suriname (lihat Utomo, 2004).

19. Tulisan ini merupakan saduran dari hasil penelitian PKP2A III LAN Samarinda Tahun 2005 dengan Judul “Kajian Tentang Budaya Kerja Organisasi Pemerintah Daerah di Kalimantan”

20. Penulis adalah Staf Peneliti Pada Bidang Kajian Aparatur, Pusat Kajian dan Pendidikan dan Pelatihan Aparatur III (PKP2A III) LAN Samarinda. 
Tidak aneh jika kemudian berbagai negara gencar melakukan program reformasi birokrasi. Reformasi birokrasi sendiri memang sebuah proses dan tuntutan yang tidak bisa ditunda lagi. Sebab, birokrasi pada hakekatnya adalah mesin negara the machine of the state) yang berfungsi menjalankan seluruh tugas pemerintahan dan pembangunan dalam rangka merealisasikan tujuan negara sebagaimana termaktub dalam konstitusi negara. Selanjutnya, inti dari birokrasi adalah SDM aparatur. Hal ini mengandung pengertian bahwa peningkatan kompetensi individual pegawai dan kompetensi jabatan struktural maupun fungsional, serta pembenahan perilaku dan etika pejabat publik perlu mendapat perhatian serius sebagai bagian integral dari proses reformasi birokrasi. Dengan kata lain, profesionalisme birokrasi akan dapat dicerminkan dari kemampuan dan kualitas SDM aparaturnya.

Berbagai upaya sudah dijalankan, mulai dari penataran P4, Gerakan Disiplin Nasional GDN), instrumen penilaian dengan DP3, sampai implementasi Waskat pengawasan melekat) dan Tim Anti Korupsi, namun sejauh ini belum nampak hasil seperti yang diharapkan. Pada tataran kesisteman juga telah dilakukan berbagai upaya dengan berbagai pendekatan teoretis / konseptual seperti privatisasi dan perubahan ekonomi perencanaan menjadi ekonomi pasar Savas, 1987; World Bank, 1996); reinventing government David Osborne dan Ted Gaebler, 1992); knowlegde-creating organization Ikujiro Nonaka dan Hirotaka Takeuchi, 1995); learning organization sebagai disiplin ke-5 Peter Senge, 1995); banishing bureaucracy David Osborne dan Peter Plastrik, 1996); dan lain-lain. Namun nampaknya, kondisi dan kinerja birokrasi masih belum menampakkan hasil positif.

Paparan diatas menyiratkan bahwa ada sesuatu yang salah pada organisasi pemerintahan di Indonesia, termasuk para aparatnya. Salah satu yang patut diperhatikan adalah masalah budaya kerja organisasi, termasuk pula masalah sikap profesionalisme, etika, semangat pengabdian, komitmen terhadap tugas, serta motivasi dari setiap insan pelayanan publik. Dalam kaitan ini, MENPAN telah merumuskan 17 perilaku persepsi, sikap dan cara kerja sebagai indikator peningkatan budaya kerja yaitu perilaku-perilaku yang dianggap perlu ditingkatkan untuk peningkatan fungsi pelayanan aparatur negara baik kepada masyarakat, maupun ke dalam instansi sendiri dan antar instansi pemerintah). Ke-17 perilaku tersebut adalah:

1. Komitmen terhadap visi, misi, organisasi, tujaun dan konsistensinya dalam pelaksanaan kebijakan negara serta peraturan perundangan yang berlaku.

2. Wewenang dan tanggung jawab.

3. Keikhlasan dan kejujuran.

4. Integritas dan profesionalisme.

5. Kreativitas dan kepekaan sensitivitas) terhadap lingkungan tugas.

6. Kepemimpinan dan keteladanan.

7. Kebersamaan dan dinamika kelompok/organisasi.

8. Ketepatan keakurasian) dan kecepatan.

9. Rasionalitas dan emosi.

10. Keteguhan dan ketegasan.

11. Disiplin dan keteraturan bekerja.

12. Keberanian dan kearifan dalam mengambil keputusan/menganai konflik.

13. Dedikasi dan loyalitas.

14. Semangat dan motivasi.

15. Ketekunan dan kesabaran. 
16. Keadilan dan keterbukaan.

17. Penguasaan ilmu pengetahuan dan teknologi yang diperlukan untuk melaksanakan tugas/pekerjaannya.

Dari latar belakang di atas dapat dirumuskan adanya beberapa permasalahan penelitian, yaitu masih ditemuinya praktek-praktek penyelenggaraan pemerintahan yang tidak sesuai dengan budaya kerja organisasi sehingga kurang dapat berkontribusi secara optimal untuk menciptakan efektivitas, efisiensi, dan kinerja organisasi pemerintahan daerah secara optimal serta masih adanya indikasi bahwa kebijakan pemerintah daerah selama ini kurang terprogram secara sistematis untuk menciptakan budaya kerja yang kondusif di lingkungannya masing-masing.

\section{Tujuan Penelitian dan Metodologi}

Penelitian ini bertujuan untuk mengetahui kondisi dan implementasi budaya kerja organisasi pemerintahan, atau menilai dan mengkaji sejauhmana praktek penyelenggaraan pemerintahan daerah telah bersesuaian dengan prinsip-prinsip budaya kerja sebagaimana ditetapkan oleh MENPAN serta untuk mencari alternatif kebijakan yang lebih operasional dalam menumbuhkan dan membangun budaya kerja organisasi pemerintah daerah, sehingga dapat memacu kinerja organisasi sektor publik secara lebih baik.

Penelitian yang dilakukan ini merupakan penelitian persepsi yang sesuai dengan tujuannya dirancang untuk dapat menguraikan, menjawab, dan menjabarkan kondisi dan implementasi budaya kerja organisasi pemerintahan di Kalimantan. Pengambilan sampel dilakukan dengan menggunakan metode stratified purposive sampling. Adapun teknik pengumpulan data dilakukan dengan Penyebaran dan pengisian kuesioner, Penjaringan data sekunder untuk menunjang analisis, seperti laporan kegiatan, hasil penelitian, dan sebagainya.

Penelitian ini akan memfokuskan pada 17 (tujuh belas) sub-variabel dari variable kepemerintahan yang baik (good governance) sebagaimana yang telah dirumuskan oleh MENPAN. Selanjutnya, ketujuh belas sub-variabel tadi akan dijabarkan lebih lanjut dalam bentuk indikator-indikatornya, yang pengukurannya akan menggunakan skala Likert, yang akan dianalisis secara deskriptif dengan menggunakan teknis nilai rata-rata dan kemudian diinterpretasikan secara naratif.

\section{Arti dan Makna Budaya Kerja}

Budaya Kerja secara harfiahnya terdiri dari dari dua kata yaitu budaya dan kerja, kata budaya berasal dari bahasa sanksekerta "budhayah", bentuk jamak dari budhi yang artinya 'akal atau segala sesuatu yang berkaitan dengan akal pikiran, nilai-nilai dan sikap mental'. Budi daya berarti memberdayakan budi sebagaimana alam bahasa inggris dikenal culture yang artinya mengolah atau mengerjakan sesuatu (pertanian) yang kemudian berkembang sebagai cara manuasia mengaktualisasikan rasa (value), karsa (creativity) dan karya-karyanya (performance).

Menurut Koentjaraningrat (2000) Budaya diartikan sebagai keseluruhan sistem gagasan tindakan dan hasil karya manusia dalam rangka kehidupan masyarakat yang dijadikan milik diri manusia dengan cara belajar. Dari pengertian tersebut budaya mengandung makna 
sebagai berikut: 1) Adanya pola nilai, sikap tingkah laku termasuk bahasa, hasil karsa dan karya; 2) Budaya berkaitan erat dengan persepsi terhadap nilai dan lingkungannya yang melahirkan mkana dan pandangan hidup, yang yang akan mempengaruhi sikap dan tingkah laku; 3) Budaya merupakan hasil dari pengalaman hidup, kebiasaan-kebiasaan serta proses seleksi terhadap norma-norma yang ada dalam cara dirinya berinteraksi sosial atau menempatkan dirinya di tengah-tengah lingkungan tertentu; dan 4) Dalam proses budaya terdapat proses saling mempengaruhi dan saling ketergantungan, baik sosial maupun lingkungan non-sosial.

Sementara kata kerja dapat diartikan sebagai berikut: 1) Kerja adalah hukuman. Manusia sebenarnya hidup bahagia tanpa kerja di Taman Firdaus, tetapi karena ia jatuh ke dalam dosa, maka ia dihukum: untuk bisa hidup sebentar manusia harus bekerja banting tulang cari makan. Salah satu bentuk hukuman adalah kerja paksa; 2) Kerja adalah beban. Bagi orang malas, kerja adalah beban. Juga bagi kaum budak atau pekerja yang berada dalam posisi lemah; 3) Kerja adalah kewajiban. Dalam birokrasi atau kontraktual, kerja adalah kewajiban, guna memenuhi perintah atau mernbayar hutang; 4) Kerja adalah sumber penghasilan. Hal ini jelas. Kerja sebagai sumber nafkah merupakan anggapan dasar masyarakat pada umumnya; 5) Kerja adalah kesenangan. Kerja sebagai kesenangan seakan hobi atau sport. Hal ini ada kaitannya dengan leisure, sampai pada yang workaholic; 6) Kerja adalah gengsi, prestise. Kerja sebagai gengsi berkaitan dengan status dan jabatan. Jabatan struktural misalnya, jauh lebih diidamkan ketimbang jabatan fungsional; 7) Kerja adalah aktualisasi diri. Disini kerja dikaitkan dengan peran, cita-cita atau ambisi. Bagi seseorang yang menganut anggapan dasar ini, lebih baik jadi kepala ayam ketimbang ekor sapi; 8) Kerja adalah panggilan jiwa. Kerja di sini berkaitan dengan ba';at. Dari sini tumbuh profesionalisme dan pengabdian kepada kerja; 9) Kerja adalah pengabdian dengan tulus, tanpa pamrih; 10) Kerja adalah hidup. Hidup diabdikan dan diisi unt'ak dan dengan kerja; 11) Kerja adalah ibadah. Kerja merupakan bukti pengabdian dan rasa syukur untuk mengolah dan memenuhi panggilan illahi; dan 12) Kerja adalah suci. Kerja harus dihormati dan jangan dicemarkan dengan perbuatan dosa, kesalahan, pelanggaran dan kejahatan. menurut Jalaluddin Rachmat (2003) "Kerja" adalah segala kegiatan ekonomis yang dimaksudkan untuk memperoleh upah, baik berupa kerja fisik material atau kerja intelektual.

Budaya Kerja sebagai refleksi dari Kata "Budaya” dan ”kerja” dalam Keputusan Menteri Pendayagunaan Aparatur Negara RI No.25/KEP/M.PAN/4/2002 diartikan sebagai sikap dan perilaku individu dan kelompok aparatur negara yang didasari atas nilai-nilai yang diyakini kebenarannya dan telah menjadi sifat serta kebiasaan dalam melaksanakan tugas dan pekerjaannya sehari-hari. Proses pembentukan sikap dan perilaku itu diarahkan kepada terciptanya aparatur negara yang profesional, bermoral yang memiliki persepsi yang tepat terhadap pekerjaan, sehingga prestasi kerja merupakan aktualisasi jati dirinya sedangkan dalam Pengembangan Budaya Kerja dalam Perspektif Islam (2003) Budaya Kerja merupakan pola tingkah laku dan nilai-nilai yang disepakati karyawan dalam bekerja, misalnya perilaku dalam menjalankan tugas, karier, promosi, reward dan sebagainya. 


\section{Nilai-Nilai Budaya Kerja Yang Melekat Pada Kebijakan}

Budaya kerja di samping dipengaruhi oleh nilai-nilai yang tumbuh dan berkembang di masyarakat dalam pelaksanaannya dipengaruhi pula oleh nilai yang melekat dalam kebijakan sebagai dasar dalam pelaksanaan tugas aparatur. Beberapa peraturan perundang-undangan yang memuat nilai-nilai budaya kerja antara lain:

\section{Undang-Undang Dasar 1945}

Dalam UUD 1945 terdapat rumusan mengenai landasan falsafah Negara Republik Indonesia yang disebut Pancasila, yang merupakan nilai-nilai yang hakiki, termanifestasikan dalam simbol-simbol kehidupan bangsa, menandai realitas sosial masyarakat bangsa di seluruh wilayah negara, menjadi nilai pemersatu kehidupannya sebagai bangsa, serta sebagai pandangan hidup bangsa dan falsafah negara atau falsafah dalam bernegara. Penempatan falsafah negara tersebut dalam konstitusi negara mengimperasikan bahwa keseluruhan sistem dan proses penyelenggaraan negara dan pembangunan bangsa harus didasarkan, mengacu, dan diarahkan pada perwujudan nilainilai yang terkandung di dalamnya. Konsep dan praktek penyelenggaraan negara, tidak boleh meninggalkan nilai-nilai yang terkandung dalam falsafah negara yang sekaligus menjadi dasar NKRI. Sebaliknya, ia berkewajiban untuk mewujudkannya; dalam arti seluruh dan setiap unsur penyelenggara negara, aparatur pemerintahan negara dan masyarakat bangsa secara individual ataupun institusional, harus menjadikan nilai-nilai Pancasila sebagai "pedoman perilaku dalam berpikir dan bertindak" dalam rangka kehidupan bermasyarakat, berbangsa, dan bernegara. Keutuhan nilai Pancasila harus dijaga sehingga merupakan cara pandang yang bulat; maksudnya, kelima sila dari Pancasila itu harus dipandang dan diaplikasikan secara utuh, sebagai kesatuan nilai yang tidak terpisahkan satu sama lain; sila yang satu tidak boleh terlepas dari sila yang lain.

2. TAP MPR No. VI/MPR/2001 tentang Etika Kehidupan Berbangsa Memberi Dasar Bagi Pengejawantahan Etika Dalam Proses Kehidupan Berbangsa dan Bernegara. TAP tersebut menjelaskan bahwa etika dalam kehidupan berbangsa merupakan satu wahana dalam rangka kelancaran penyelenggraan Sistem Administrasi Negara dimana dengan adanya etika yang dipahami dan menjadi dasar pola perilaku dalam berbangsa dan bernegara akan mengarah pada satu tatanan kenegaraan yang stabil, karena persepsi akan perilaku yang diharapkan oleh masing-masing individu sebagai warga negara dapat teramalkan dengan baik. Pokok-pokok etika dalam kehidupan berbangsa mengedepankan kejujuran, amanah, keteladanan, sportivitas, disiplin, etos kerja, kemandirian, sikap toleransi, rasa malu, tanggung jawab, menjaga kehormatan serta martabat diri sebagai warga negara. Etika kehidupan berbangsa ini meliputi etika sosial dan budaya, etika politik dan pemerintahan, etika ekonomi dan bisnis, etika penegakan hukum, etika keilmuan, dan etika lingkungan. 
3. TAP MPR No. XIIMPR/1998 tentang Penyelenggaraan Negara yang Bersih dan Bebas dari Korupsi, Kolusi, dan Nepotisme

MPR RI berketetapan untuk memfungsikan secara proporsional dan benar Lembaga Tinggi Negara, dan Lembaga Kepresidenan, sehingga penyelenggaraan Negara berlangsung sesuai dengan UUD 1945. Dalam kaitan ini, penyelenggara negara pada lembaga-lembaga eksekutif, legislatif, dan yudikatif harus melaksanakan fungsi dan tugasnya dengan baik dan bertanggung jawab kepada masyarakat, bangsa, dan negara. Untuk menjalankan fungsi dan tugasnya tersebut, penyelenggara negara harus jujur, adil, terbuka, dan terpercaya, serta mampu membebaskan diri dari prektek korupsi, kolusi, dan nepotisme.

4. UU No. 43 Tahun 1999 tentang Perubahan Atas UU No. 8 Tahun 1974 tentang Pokok-Pokok Kepegawaian

Pegawai Negeri berkedudukan sebagai unsur aparatur Negara yang bertugas untuk memberikan pelayanan kepada masyarakat secara profesional, jujur, adil, dan merata dalam penyelenggaraan tugas Negara, pemerintahan, dan pembangunan. Dalam kedudukan dan tugas tersebut, Pegawai Negeri harus netral dari pengaruh semua golongan dan partai politik serta tidak diskriminatif dalam memberikan pelayanan kepada masyarakat. Untuk menjamin netralitas, Pegawai Negeri dilarang menjadi anggota dan/atau pengurus partai politik. Setiap pegawai negeri wajib mentaati segala peraturan Perundang-Undangan yang berlaku dan melaksanakan tugas kedinasan yang dipercayakan kepadanya dengan penuh pengabdian, kesadaran, dan tanggungjawab. Dalam rangka lebih meningkatkan pembinaan, keutuhan, dan kekompakan serta dalam rangka usaha menjamin kesetiaan, dan ketaatan penuh seluruh Pegawai Negeri Sipil terhadap Pancasila, UndangUndang Dasar 1945, Negara dan Pemerintah, perlu dipupuk dan dikembangkan jiwa korps yang bulat di kalangan Pegawai Negeri Sipil.

5. UU No. 28 Tahun 1999 tentang Penyelenggaraan Negara yang Bersih dan Bebas dari Korupsi, Kolusi dan Nepotisme

Dikeluarkannya UU ini bertujuan untuk meningkatkan akuntabilitas penyelenggaraan Negara/Pemerintahan, Setiap penyelenggara negara berhak untuk: (1) menerima gaji, tunjangan, dan fasilitas lainnya sesuai dengan ketentuan peraturan Perundang-Undangan yang berlaku; (2) menggunakan hak jawab terhadap setiap teguran, tindakan dari atasannya, ancaman hukuman, dan kritik masyarakat; (3) menyampaikan pendapat di muka umum secara bertanggung javvab sesuai dengan wewenangnya; dan (4) mendapatkan hak-hak lain sesuai dengan ketentuan peraturan Perundang-Undangan yang berlaku. Disamping hak-hak tersebut di atas, setiap penyelenggara negara berkewajiban untuk: (1) mengucapkan sumpah atau janji sesuai dengan agamanya sebelum memangku jabatannya; (2) bersedia diperiksa kekayaannya sebelum, selama dan setelah menjabat; (3) melaporkan dan mengumumkan kekayaannya sebelum dan setelah menjabat; (4) tidak melakukan perbuatan korupsi, kolusi, dan nepotisme; (5) melaksanakan tugas tanpa membedabedakan suku, agama, ras, dan golongan; (6) melaksanakan tugas dengan penuh rasa tanggungjawab dan tidak melakukan perbuatan tercela, tanpa pamrih baik untuk 
kepentingan pribadi, keluarga, kroni, maupun kelompok, dan tidak mengharapkan imbalan dalam bentuk apa pun yang bertentangan dengan ketentuan peraturan PerundangUndangan yang berlaku; dan (7) bersedia menjadi saksi dalam perkara korupsi, kolusi dan nepotisme serta dalam perkara lainnya sesuai dengan ketentuan peraturan PerundangUndangan yang berlaku. Hubungan antar penyelenggara negara dilaksanakan dengan mentaati norma-norma kelembagaan, kesopanan, kesusilaan, dan etika berlandaskan Pancasila dan Undang-Undang Dasar 1945.

6. UU No. 20 Tahun 2001 tentang Perubahan atas UU No. 31 Tahun 1999 tentang Pemberantasan Tindak Pidana Korupsi, serta UU No. 30 Tahun 2002 tentang Komisi Pemberantasan Tindak Pidana Korupsi

Di samping telah dikeluarkan undang-undang tentang pemberantasan tindak pidana korupsi sebagaimana tersebut di atas, selanjutnya dikeluarkan UU No. 30 tahun 2002 tentang komisi pemberantasan tindak pidana korupsi. Undang-Undang tersebut mengatur antara lain tugas, wewenang dan kewajiban Komisi Pemberantasan Korupsi, dalam rangka penyelenggaraan Negara yang bersih dan bebas dari Korupsi, Kolusi dan Nepotisme.

7. Peraturan Pemerintah No. 30 Tahun 1980 tentang Peraturan Disiplin Pegawai Negeri Sipil serta PP No. 42/2004 tentang Pembinaan Jiwa Koprs dan Kode Etik Pegawai Negeri Sipil

PP No. 30 Tahun 1980 mengatur mengenai kewajiban dan larangan bagi PNS. Sedangkan PP No. 42 Tahun 2004 menjelaskan bahwa Jiwa Korps Pegawai Negeri Sipil adalah rasa kesatuan dan persatuan, kebersamaan, kerjasama, tanggungjawab, dedikasi, disiplin, kreativitas, kebanggaan dan rasa memili orgnisasi Pegawai Negeri Sipil dan kesatuan Negara Kesatuan Republik Indonesia. Sedangkan Kode Etik Pegawai Negeri Sipil adalah pedoman sikap, tingkah laku, dan perbuatan Pegawai Negeri Sipil di dalam melaksanakan tugasnya dan pergaulan hidup sehari-hari.

8. Keputusan Menteri Negara Pendayagunaan Aparatur Negara No. 04 Tahun 1991 Tentang Pedoman Pemasyarakatan Budaya Kerja

Pedoman tersebut memuat: (1) Rencana Operasional Program Budaya Kerja; (2) Budaya Kerja dan Keberhasilan Administrasi Pemerintahan; (3) Kegiatan Pimpinan Departemen/Lembaga/ Kantor/Unit dalam rangka Budaya Kerja;(4) Peranan Fasilitator; (5) Petunjuk Pembentukan Kelompok Budaya Kerja; dan (6) Alat dan Teknik untuk Kelompok Budaya Kerja. Dalam Pedoman pemasyarakatan Budaya Kerja disebutkan mengenai Falsafah Budaya Kerja: Budaya kerja merupakan sikap hidup yang didasari oleh pandangan hidup sebagai nilai-nilai yang telah menjadi sifat, kebiasaan dan kekuatan pendorong yang membudaya dalam kehidupan suatu kelompok masyarakat/ organisasi, yang kemudian tercermin dalam perilaku, kepercayaan, cita-cita pendapat dan tindakan yang terwujud sebagai "kerja" atau "bekerja". Arti Budaya Kerja aparatur adalah pengelolaan administrasi pemerintah yang mencakup pengembangan, perencanaan; produksi dan pelayanan suatu produk yang berkualitas dalam arti optimal, ekonomis dan 
bermanfaat. Produktivitas budaya kerja adalah sikap mental yang selalu mencari perbaikan atau penyempurnaan apa yang telah dicapai, dengan menerapkan teori-teori dan metodametoda baru serta yakin akan kemajuan umat manusia.

9. Keputusan Kementerian Pendayagunaan Aparatur Negara No. 25/KEP/ M.PAN/4/2002 tentang Pedoman Pengembangan Budaya Aparatur Negara

Sebagai penyempurnaan Keputusan Menteri Negara Pendayagunaan Aparatur Negara No. 04/1991 Tentang Pedoman Pemasyarakatan Budaya Kerja, dikeluarkan Keputusan Kementerian PAN No. 25/KEP/M.PAN/4/2002 tentang Pedoman Pengembangan Budaya Kerja Aparatur Negara, antara lain memuat (1) kebijakan pengembangan budaya kerja aparatur, (2) nilai-nilai dasar budaya kerja aparatur negara, (3) penerapan nilai-nilai budaya kerja aparatur negara, dan (4) sosialisasi pengembangan budaya kerja aparatur negara.

10. Keputusan Kementerian Pendayagunaan Aparatur Negara No. 63/ KEP/ M.PAN/7/2003 tentang Pedoman Umum Penyelenggaraan Pelayanan Publik

Pelaksanaan budaya kerja berkaitan dengan penyelenggaraan pelayanan publik karena pelayanan publik pada hakekatnya adalah pemberian pelayanan prima kepada masyarakat yang merupakan perwujudan kewajiban aparatur pemerintah sebagai abdi masyarakat. Dalam rangka penyelenggaraan pelayanan publik, Kementerian PAN mengeluarkan pedoman umum penyelenggaraan pelayanan publik. Pedoman umum penyelenggaraan pelayanan publik, antara lain memuat asas dan prinsip pelayanan publik.

\section{Implementasi Nilai-Nilai Budaya Kerja Aparatur di Wilayah Kalimantan}

Secara umum dapat diidentifikasikan bahwa 17 nilai dasar Budaya Kerja yang dirumuskan oleh MENPAN telah diterapkan dengan baik di wilayah Kalimantan yaitu dengan skor 4,10. Jawaban Responden menggambarkan bahwa indikator terbaik adalah Dedikasi dan Loyalitas dengan skor 4,24, kemudian secara berurutan disusul oleh Ketekunan dan Kesabaran (4,21), Penguasaan Iptek yang diperlukan untuk melaksanakan tugas (18), Semangat dan Motivasi(4,16), Keadilan dan Keterbukaan (4,16), Wewenang dan Tanggung Jawab(4,15), Disiplin dan Keteraturan Kerja (4,14), Keteguhan dan Ketegasan $(4,13)$, Kepeimpinan dan Keteladanan (4,12), Kebersamaan dan Dinamika Kelompok Organisasi $(4,11)$, Komitmen terhadap Visi, Misi Organisasi kebijakan dan Perundang-undangan yang berlaku (4,09), Keikhlasan dan Kejujuran (4,09), Keberanian dan Kearifan dalam Mengambil Keputusan/Menangani Konflik (4,06), Rasionalitas dan Emosi (4,00), Ketepatan (Keakurasian) dan kecepatan $(3,94)$, Integritas dan Profesionalitas $(3,93)$ dan indikator yang terendah/terlemah adalah Kreativitas dan Kepekaan terhadap Lingkungan Tugas yaitu dengan skor 3,88 .

Hal ini mengindikasikan bahwa aparatur di wilayah Kalimantan harus lebih berusaha memberikan ide dan saran yang baik dan berguna dalam pengembangan organisasi, 
menciptakan cara-cara kerja baru dalam menangani persoalan dan pekerjaan, berusaha mengetahui kelemahan dan kekuatan organisasi serta memiliki kemampuan antisipatif terhadap hambatan yang ada atau datang dari lingkungan organisasi dan setiap aparatur hendaknya memiliki kemauan dan kemampuan untuk melakukan proses pembelajaran terhadap persoalan, kemajuan iptek serta isu-isu yang berkembang dalam masyarakat yang berkaitan dengan organisasi, di samping itu aparatur pemerintah hendaknya terus lebih meningkatkan profesionalismenya khususnya yang menyangkut bidang tugasnya sehingga akan menampakkan hasil kerja yang produktif dan berkualitas untuk merubah asumsi dari masyarakat bahwa aparatur pemerintah "tidak profesional”. Indikator-indikator lain juga perlu terus ditingkatkan lagi penerapannya dalam melaksanakan tugas aparatur pemerintah daerah.

Pencapaian 17 nilai dasar Budaya Kerja dari seluruh Kabupaten/Kota yang disurvei menunjukkan kondisi yang cukup beragam misalnya saja pada indikator Penguasaan iptek yang diperlukan untuk melaksanakan tugas pada Kabupaten Banjar Baru dinilai dengan Skor 4,65 sementara pada tiga daerah lainnya cukup seragam kondisinya. Namun jika dilihat dari skornya indikator yang terendah dalam membangun Budaya Kerja enunjukkan kondisi yang cukup seragam pada ke-4 daerah yang disurvei.

Dilihat dari daerah yang disurvei menunjukkan kondisi yang relatif seragam, dimana skor seluruh daerah masuk pada kategori "Baik”. Meskipun ke-17 nilai dasar Budaya Kerja yang dirumuskan oleh MENPAN sudah diterapkan dengan baik, akan tetapi pengaruhnya terhadap budaya kerja aparatur itu sendiri belumlah diketahui, apalagi jika melihat realita di lapangan.

Secara lebih terinci, jawaban responden dan skor rata-rata setiap jawaban terhadap ke-17 prinsip budaya kerja dapat dilihat pada table dibawah ini.

Tabel 1

Implementasi Nilai-Nilai Budaya Kerja di 4 Kabupaten/Kota di Kalimantan

\begin{tabular}{|c|c|c|c|c|c|c|}
\hline \multirow[b]{2}{*}{ NO } & \multirow[b]{2}{*}{ INDIKATOR } & \multicolumn{4}{|c|}{ SKOR RATA-RATA \& KATEGORI } & \multirow{2}{*}{$\begin{array}{l}\text { SKOR } \\
\text { RATA- } \\
\text { RATA }\end{array}$} \\
\hline & & SINGKAWANG & $\begin{array}{c}\text { BANJAR } \\
\text { BARU }\end{array}$ & KAPUAS & KUTIM & \\
\hline 1 & $\begin{array}{l}\text { Komitmen Terhadap Visi, } \\
\text { Misi, Organisasi, Tujuan, } \\
\text { Kebijakan dan Perundang- } \\
\text { undangan yang Berlaku }\end{array}$ & $4,12(B)$ & 3,94 (B) & 4,26 (SB) & 3,99 (B) & 4,09 (B) \\
\hline 2 & $\begin{array}{l}\text { Wewenang dan Tanggung } \\
\text { Jawab }\end{array}$ & 4,15 (B) & 3,77 (B) & 4,28 (SB) & $4,17(B)$ & 4,15 (B) \\
\hline 3 & Keikhlasan dan Kejujuran & $4,10(B)$ & $4,02(B)$ & $4,08(\mathrm{~B})$ & $4,11(\mathrm{~B})$ & $4,09(\mathrm{~B})$ \\
\hline 4 & $\begin{array}{l}\text { Integritas dan } \\
\text { Profesionalitas }\end{array}$ & 3,90 (B) & 3,85 (B) & 4,06 (B) & $3,89(\mathrm{~B})$ & $3,93(\mathrm{~B})$ \\
\hline 5 & Kreativitas dan Kepekaan & 3,87 (B) & 3,79 (B) & 3,88 (B) & $3,92(\mathrm{~B})$ & $3,88(\mathrm{~B})$ \\
\hline
\end{tabular}




\begin{tabular}{|c|c|c|c|c|c|c|}
\hline & $\begin{array}{l}\text { terhadap Lingkungan } \\
\text { Tugas }\end{array}$ & & & & & \\
\hline 6 & $\begin{array}{l}\text { Kepemimpinan dan } \\
\text { Keteladanan }\end{array}$ & 4,19 (B) & 4,10 (B) & $4,14(\mathrm{~B})$ & $4,06(\mathrm{~B})$ & $4,12(B)$ \\
\hline 7 & $\begin{array}{l}\text { Kebersamaan dan } \\
\text { Dinamika Kelompok } \\
\text { Organisasi }\end{array}$ & 4,20 (SB) & 4,00 (B) & 4,08 (B) & 4,09 (B) & $4,11(\mathrm{~B})$ \\
\hline 8 & $\begin{array}{l}\text { Ketepatan (Keakurasian) } \\
\text { dan Kecepatan }\end{array}$ & 3,93 (B) & 3,73 (B) & 3,98 (B) & 3,99 (B) & $3,94(B)$ \\
\hline 9 & Rasionalitas dan Emosi & 3,99 (B) & 3,96 (B) & $4,04(\mathrm{~B})$ & $3,98(\mathrm{~B})$ & $4,00(\mathrm{~B})$ \\
\hline 10 & Keteguhan dan Ketegasan & 4,09 (B) & 3,92 (B) & $4,13(\mathrm{~B})$ & $\begin{array}{l}4,23 \\
(\mathrm{SB})\end{array}$ & $4,13(\mathrm{~B})$ \\
\hline 11 & $\begin{array}{l}\text { Disiplin dan Keteraturan } \\
\text { Kerja }\end{array}$ & $4,22(\mathrm{SB})$ & 3,98 (B) & 3,98 (B) & $\begin{array}{l}4,26 \\
(\mathrm{SB})\end{array}$ & $4,14(\mathrm{~B})$ \\
\hline 12 & $\begin{array}{l}\text { Keberanian dan Kearifan } \\
\text { dalam Mengambil } \\
\text { Keputusan/Menangani } \\
\text { Konflik }\end{array}$ & 4,08 (B) & 4,04 (B) & $4,13(\mathrm{~B})$ & $4,00(\mathrm{~B})$ & $4,06(\mathrm{~B})$ \\
\hline 13 & Dedikasi dan Loyalitas & $4,23(\mathrm{SB})$ & 4,29 (SB) & 4,09 (B) & $\begin{array}{l}4,35 \\
\text { (SB) }\end{array}$ & $\begin{array}{l}4,24 \\
\text { (SB) }\end{array}$ \\
\hline 14 & Semangat dan Motivasi & $4,16(B)$ & $4,17(B)$ & $4,12(\mathrm{~B})$ & $4,18(\mathrm{~B})$ & $4,16(\mathrm{~B})$ \\
\hline 15 & Ketekunan dan Kesabaran & $4,14(B)$ & 4,38 (SB) & 4,15 (B) & $\begin{array}{l}4,26 \\
(\mathrm{SB})\end{array}$ & $\begin{array}{l}4,21 \\
(\mathrm{SB})\end{array}$ \\
\hline 16 & Keadilan dan Keterbukaan & $4,11(B)$ & $4,54(\mathrm{SB})$ & $4,06(\mathrm{~B})$ & $4,15(\mathrm{~B})$ & $4,16(\mathrm{~B})$ \\
\hline 17 & $\begin{array}{l}\text { Penguasaan Iptek yang } \\
\text { diperlukan untuk } \\
\text { melaksanakan Tugas }\end{array}$ & 4,05 (B) & 4,65 (SB) & 4,11 (B) & 4,18 (B) & 4,18 (B) \\
\hline & SKOR RATA-RATA & 4,09 (B) & $4,08(B)$ & 4,09 (B) & $4,11(B)$ & $4,10(B)$ \\
\hline
\end{tabular}

(Sumber: Kuesioner Penelitian, 2005, diolah)

Keterangan :

SB : Sangat Baik

B : Baik 
Implementasi Nilai Dasar Budaya Kerja di Beberapa Kabupaten / Kota di Wilayah Kalimantan

\section{Kota Singkawang (Kalimantan Barat)}

Kota Singkawang merupakan salah satu Daerah Tingkat II di Provinsi Kalimantan Barat yang terletak pada bagian barat wilayah provinsi Kalimantan Barat Berdasarkan Tabel di atas. Secara umum implementasi nilai-nilai dasar Budaya Kerja di Kota singkawang sudah baik. Meskipun demikian, masih perlu adanya pembenahan terhadap 17 nilai dasar/indikator budaya kerja terutama terhadap indikator kreativitas dan kepekaan terhadap lingkungan tugas, Integritas dan Profesionalitas, Ketepatan (Keakurasian) dan Kecepatan serta Rasionalitas dan Emosi dalam menjalankan tugas. Kondisi 17 Indikator tersebut dapat dijelaskan sebagai berikut:

a. Pada Komitmen terhadap Visi Misi Organisasi, Tujuan, Kebijakan dan Perundangundangan yang Berlaku masih ada beberapa aspek yang perlu diperbaiki terutama dalam aspek Realisasi Pelaksanaan Program/Kegiatan yang dicanangkan.

b. Untuk indikator Wewenang dan Tanggung Jawab, aspek yang perlu diperbaiki terutama sikap menanggung segala sesuatu dalam menjalankan tugasnya dan dalam menggunakan kewenangan untuk menciptakan iklim/kondisikerja serta arahan kerja.

c. Untuk indikator Keikhlasan dan Kejujuran, aspek yang perlu diperbaiki terutama pada keikhlasan dan kejujuran aparatur dalam menjalankan tugas dan kewenangannya.

d. Untuk indikator Integritas dan Profesional, aspek yang perlu diperbaiki adalah kecakapan dan penguasaan segala seluk-beluk bidang tugasnya.

e. Untuk indikator Kreativitas dan Kepekaan terhadap Lingkungan Tugas yang merupakan indikator paling lemah, aspek yang perlu diperbaiki terutama kemampuan mengetahui kelemahan dan kekuatan organisasi serta memiliki kemampuan antisipatif terhadap peluang dan hambatan yang ada atau datang dari lingkungan organisasi serta penggunaan cara-cara kerja baru dalam menangani persoalan dan pekerjaan yang ada dalam organisasi.

f. Untuk indikator Kepemimpinan dan Keteladanan, aspek yang perlu terus diperbaiki terutama kemampuan mengemukakan pendapat dan arahan yang jelas, benar dan tepat.

g. Untuk indikator Kebersamaan dan Dinamika Kelompok/Organisasi, aspek yang harus diperbaiki terutama kedinamisan dan kemampuan menempatkan diri dan bekerja pada setiap situasi kerja di lingkungan organisasi serta kemampuan menyelesaikan persoalan-persoalan organisasi.

h. Untuk indikator Ketepatan (keakurasian) dan Kecepatan, aspek yang perlu diperbaiki terutama serta pelaksanaan tugas dan/atau pekerjaan secara terukur, tepat, dan cepat.

i. Untuk indikator Rasionalitas dan Emosi, aspek yang perlu terus diperbaiki terutama perilaku bertindak dan bekerja secara dewasa serta pengoperasionalisasikan uraian tugas pokok organisasi (unit kerja) dalam tindakan atau program/kegiatan yang nyata dan masuk akal.

j. Untuk indikator Keteguhan dan Ketegasan, aspek yang perlu terus diperbaiki terutama dalam mempertahankan pendapat dan ide-ide yang berhubungan dengan pembinaan dan pengembangan organisasi.

k. Untuk indikator Disiplin dan Keteraturan Kerja, aspek yang perlu diperbaiki terutama sikap dan tindakan yang menunjukkan keteraturan dalam bekerja.

1. Untuk indikator Keberanian dan Kearifan dalam Mengambil Keputusan/ Menangani Konflik, aspek yang perlu diperbaiki terutama pengambilan keputusan yang berkaitan dengan keberlangsungan kehidupan organisasi, dimana dalam pengambilan keputusan tersebut ada kecenderungan tanpa menyertakan semua pegawai dalam organisasi. 
m. Untuk indikator Dedikasi dan Loyalitas, aspek yang perlu diperbaiki terutama keoptimalan setiap pegawai dalam mengorbankan tenaga, pikiran dan waktu dalam melaksanakan tugas dan pekerjaan yang diberikan demi eksistensi dan pengembangan organisasi.

n. Untuk indikator Semangat dan Motivasi, aspek yang perlu diperabaiki terutama keteladan dalam menjalankan tugas dan kewajiban di organisasi.

o. Untuk indikator Ketekunan dan Kesabaran, aspek yang perlu diperabiki terutama ketenangan hati dalam mengahadapi berbagai persoalan internal organisasi serta kemampuan menyelesaikan setiap tugas dan tanggung jawab organisasi dengan tenang dan tidak tergesa-gesa demi tercapainya produktivitas, efektivitas dan efisiensi organisasi.

p. Untuk indikator Keadilan dan Keterbukaan, aspek yang perlu diperbaiki terutama kemauan untuk tanggung-gugat secara terbuka, hal-hal di dalam organisasi yang berkaitan dengan kepentingan atau urusan masyarakat.

q. Untuk indikator Penguasan Iptek yang Diperlukan untuk Melaksanakan Tugas, aspek yang perlu diperbaiki terutama kemampuan untuk mengoperasionalkan mesin ketik dan/atau komputer minimal Microsoft Word, guna membantu kelancaran pelaksanaan tugas atau pekerjaan administratif organisasi. Aspek ini sebenarnya merupakan aspek yang sangat penting untuk dikuasai oleh seorang pegawai dalam menjalankan tugasnya, di samping didasarkan pada kemampuan individu akan tetapi seharusnya sangatlah mendapatkan perhatian dari pemerintah, karena merupakan kemampuan dasar yang seharusnya dikuasai oleh seorang pegawai.

\section{Kabupaten Kutai Timur (Kalimantan Timur)}

Kabupaten Kutai Timur termasuk wilayah administrasi Provinsi Kalimantan Timur hasil pemekaran. Dari persepsi responden yang ada terlihat bahwa implementasi terhadap Ke-17 indikator budaya kerja sudah diterapkan dengan "baik", indikator yang perlu diperbaiki terutama Kreativitas dan kepekaan terhadap Lingkungan Tugas, Rasionalitas dan Emosi, Ketepatan (Keakurasian ) dan kecepatan, serta komitmen terhadap visi, misi, organisasi, tujuan, kebijakan dan perundang-undangan yang berlaku. Adapun Budaya Kerja di Kabupaten Kutai Timur berdasarkan jawaban responden terhadap 17 indikator yang diajukan dapat dijelaskan sebagai berikut :

a. Indikator Komitmen terhadap Visi Misi Organisasi, Tujuan, Kebijakan dan Perundang-undangan yang Berlaku masih tergolong salah satu indikator yang lemah dalam membangun Budaya kerja, aspek yang harus diperbaiki terutama realisasi pelaksanaan program/kegiatan yang dicanangkan serta program jangka panjang tertentu sudah realistis dan sesuai dengan visi dan misi organisasi perlu dilakukan evaluasi kembali karena keduanya diberikan skor dibawah rata-rata dibanding kedua aspek lainnya.

b. Untuk Indikator Wewenang dan Tanggung Jawab, aspek yang perlu diperbaiki terutama pelaksanaan hak dan kekuasaan untuk menjalankan tugas/pekerjaan kantor dan dalam memberikan pelayanan kepada masyarakat serta sikap menanggung segala sesuatu yang terjadi dalam menjalankan tugas.

c. Dalam indikator Keikhlasan dan Kejujuran, aspek yang perlu diperbaiki terutama dalam memberikan laporan kerja kepada atasan atau pimpinannya.

d. Untuk indikator Integritas dan Profesional, aspek yang harus diperbaiki terutama kecakapan dan penguasaan terhadap bidang tugasnya perlu terus ditingkatkan, disamping itu pelaksanaan tugas dan tanggung jawab organisasi oleh para pegawai yang menggambarkan hasil kerja yang produktif, berkualitas, efektif dan efisien juga perlu diperbaiki. 
e. Indikator Kreativitas dan Kepekaan terhadap Lingkungan Tugas yang merupakan indikator paling lemah, aspek yang harus diperbaiki terutama kepemilikan cara-cara kerja baru dalam menangani persoalan dan pekerjaan yang ada dalam organisasi serta kemampuan untuk mengetahui kelemahan dan kekuatan organisasi serta kemampuan antisipatif terhadap peluang dan hambatan yang ada atau datang dari lingkungan organisasi.

f. Dalam indikator Kepemimpinan dan Keteladanan, asspek yang perlu diperbaiki terutama pemberian teladan yang baik dalam kehadiran kerja, pekerjaan (tugas dan tanggung jawab) ataupun sikap dan perilaku.

g. Untuk indikator Kebersamaan dan Dinamika Kelompok/Organisasi, aspek yang perlu terus diperbaiki terutama peningkatan kemampuan menyelesaikan persoalan-persoalan organisasi dengan pertemuan-pertemuan dan/atau rapat organisasi.

h. Pada indikator Ketepatan (keakurasian) dan Kecepatan, aspek yang perlu diperbaiki terutama pelaksanaan tugas dan/atau pekerjaan secara terukur, tepat dan cepat serta penyelesaian laporan tugas dan/atau pekerjaan secara cepat dan tepat waktu.

i. Untuk indikator Rasionalitas dan Emosi, aspek yang perlu diperbaiki terutama pembuatan perencanaan kegiatan secara matang, masuk akal, dan aplikatif. Disamping setiap pegawai juga harus dapat mengoperasionalisasikan uraian tugas pokok organisasi (unit kerja) dalam tindakan atau program/kegiatan yang nyata dan masuk akal juga perlu mendapat perhatian untuk meningkatkan rasionalitas dan emosi setiap pegawai.

j. Dalam indikator indikator Keteguhan dan Ketegasan, aspek yang perlu diperbaiki terutama dalam memberikan arahan atau bimbingan terhadap bawahan dan/atau sesama pegawai dilakukan dengan jelas dan terarah dalam rangka pengembangan pegawai, organisasi dan pencapaian tujuan organisasi.

k. Untuk indikator Disiplin dan Keteraturan Kerja, aspek yang perlu diperbaiki terutama kedisiplinan pegawai yaitu masuk dan pulang kerja sesuai dengan ketentuanjam kerja yang berlaku dalam organisasi, dan jika pulang sebelum jam kerja selalu meminta izin kepada pihak yang berwenang di dalam organisasi.

l. Pada indikator Keberanian dan Kearifan dalam Mengambil Keputusan/ Menangani Konflik, aspek yang perlu diperbaiki terutama penyelesaian yang baik terhadap setiap konflik yang muncul dalam organisasi demi produktivitas, efisiensi, dan efektivitas organisasi.

m. Untuk indikator Dedikasi dan Loyalitas, aspek yang perlu diperbaiki terutama dalam memberikan pengorbanan tenaga, pikiran dan waktu dalam pelaksanaan tugas dan pekerjaan yang diberikan demi eksistensi dan pengembanagan organisasi.

n. Dalam indikator Semangat dan Motivasi, aspek yang perlu diperbaiki terutama aktivitas yang giat dan bergairah dalam menerima tugas dan tanggung jawab yang diberikan oleh atasan ataupun yang sudah menjadi kewajiban dari setiap pegawai sesuai tugas pokok dari unit yang bersangkutan di dalam organisasi dan memunculkan dorongan yang positif terhadap rekan kerja baik melalui contoh perbuatan dalam keseharian bekerja di oranisasi ataupun melalui arahan dan nasehat yang membimbing.

o. Untuk indikator Ketekunan dan Kesabaran, aspek yang perlu diperbaiki terutama keseriusan atau kesungguhan dalam melaksanakan tugas dan tanggung jawab di organisasi dan kesungguhan dalam mematuhi setiap peraturan peundang-undangan, kebijaksanaan, dan atau tujuan organisasi masih dinilai baik.

p. Pada indikator Keadilan dan Keterbukaan, aspek yang perlu terus dipebaiki terutama kemauan untuk tanggung-gugat secara terbuka, hal-hal di dalam organisasi yang berkaitan dengan kepentingan atau urusan masyarakat.

q. Dalam Indikator Penguasan Iptek yang Diperlukan untuk Melaksanakan Tugas, aspek yang perlu diperbaiki terutama kemampuan untuk mengoperasionalkan mesin ketik 
dan/atau komputer minimal Microsoft Word, guna membantu kelancaran pelaksanaan tugas atau pekerjaan administratif organisasi. Disamping itu kemampuan dan sikap berpikir yang sistematis dan edukatif dalam menggunakan kemampuan pengetahuan teknis untuk dapat dikembangkan atau ditularkan kepada orang lain atau sesama rekan kerja dalam organisasi juga perlu diperbaiki. Kedua aspek ini cukup memperlemah indikator Penguasan Iptek yang Diperlukan untuk Melaksanakan Tugas dibanding kedua aspek lainnya yang sudah dinilai sangat baik meskipun agak kurang.

\section{Kabupaten Kapuas (Kalimantan Tengah)}

Kabupaten Kapuas merupakakan slaha satu wilayah administratif Provinsi Kalimantan Tengah yang terletak di sebelah timur berbatasan dengan wilayah Provinsi Kalimantan Selatan. Dari persepsi responden yang ada terlihat bahwa implementasi terhadap Ke-17 indikator budaya kerja sudah diterapkan dengan "baik”, indikator yang perlu diperbaiki terutama Kreativitas dan kepekaan terhadap Lingkungan Tugas, Ketepatan (Keakurasian) dan kecepatan serta disiplin dan keteraturan kerja. Adapun kondisi untuk masing-masing indikator adalah sebagai berikut:

a. Pada indikator Komitmen terhadap Visi Misi Organisasi, Tujuan, Kebijakan dan Perundang-undangan yang Berlaku, aspek yang perlu diperbaiki terutama realisasi Pelaksanaan Program/Kegiatan yang dicanangkan sudah mulai menggambarkan atau mendekati visi dan misi organisasi yang ditetapkan, aspek ini merupakan yang paling lemah dalam memnbangun indikator ini.

b.Untuk indikator Wewenang dan Tanggung Jawab, aspek yang perlu diperbaiki terutama pelaksanaan hak dan kekuasaan untuk melaksanakan tugas/pekerjaan kantor dan memberikan pelayanan kepada masyarakat.

c.Dalam indikator Keikhlasan dan Kejujuran, aspek yang perlu diperbaiki terutama pemanfaatan barang dan jasa oleh pimpinan dan/atau setiap pegawai dalam memberikan pelayanan kepada masyarakat dan/atau dalam operasional kegiatan internal organisasi sudah dipertanggungjawabkan dengan baik dan terbuka.

d.Untuk indikator Integritas dan Profesional, aspek yang perlu diperbaiki terutama kecakapan dan penguasaan segala seluk-beluk bidang tugasnya, serta dalam menjalankan tugas dan tanggung jawab organisasi para pegawaii di lingkungan organisasi sudah menampakkan hasil kerja yang produktif, berkualitas, efektif, dan efisien.

e. Indikator Kreativitas dan Kepekaan terhadap Lingkungan Tugas merupakan indikator yang paling lemah dari 17 indikator Budaya Kerja, aspek yang harus diperbaiki terutama penggunaan cara-cara kerja baru dalam menangani persoalan dan pekerjaan serta kemampuan mengetahui kelemahan dan kekuatan organisasi serta memiliki kemampuan antisipatif terhadap peluang dan hambatan yang ada atau datang dari lingkungan organisasi.

f. Untuk indikator Kepemimpinan dan Keteladanan, aspek yang perlu diperbaiki terutama kemampuan untuk menggerakkan bawahan dalam melakukan tugas-tugas pokok dari setiap unit kerja organisasi guna pencapaian tujuan organisasi.

g. Dalam indikator Kebersamaan dan Dinamika Kelompok/Organisasi, aspek yang perlu diperbaiki terutama kedinamisan atau kemampuan menempatkan diri dan bekerja pada setiap situasi kerja di lingkungan organisasi.

h. Pada indikator Ketepatan (keakurasian) dan Kecepatan, aspek yang perlu diperbaiki terutama penyelesaian laporan tugas dan/atau pekerjaan secara cepat dan tepat, karena merupakan aspek yang paling lemah dalam membangun Indikator Ketepatan dan Kecepatan. 
i. Untuk indikator Rasionalitas dan Emosi, aspek yang perlu diperbaiki terutama kemampuan bekerja secara logis dan sistematis serta perilaku bertindak dan bekerja secara dewasa.

j. Dalam indikator Keteguhan dan Ketegasan, aspek yang perlu diperbaiki terutama kepastian dalam bertindak terhadap tugas dan pekerjaan yang merupakan wewenang dan tanggung jawab pegawai.

k. Pada indikator Disiplin dan Keteraturan Kerja, aspek yang perlu diperbaiki terutama kedisiplinan dalam masuk dan pulang kerja sesuai dengan ketentuan-ketentuan jam kerja yang berlaku dalam organisasi. Dan jika pulang sebelum jam kerja selalu meminta izin kepada pihak yang berwenang di dalam organisasi.

l. Untuk indikator Keberanian dan Kearifan dalam Mengambil Keputusan/ Menangani Konflik, pengambilan keputusan yang berkaitan dengan keberlangsungan kehidupan organisasi.

m. Untuk indikator Dedikasi dan Loyalitas, aspek yang perlu diperbaiki terutama dalam menjunjung tinggi kehormatan organisasi, egara, dan senantiasa mengedepankan kepentingan dan tujuan organisasi serta kepatuhan terhadap kebijakan organisasi, pimpinan dan peraturan yang berlaku.

n. Pada indikator Semangat dan Motivasi, aspek yang perlu diperbaiki terutama dalam melihat setiap pekerjaan baru sebagai suatu tantangan untuk pengembangan diri dan organisasi.

o. Dalam indikator Ketekunan dan Kesabaran, aspek yang perlu diperbaiki terutama ketenangan hati dalam menghadapi berbagai persoalan internal organisasi karena hal ini mendapatkan penilaian di bawah skor rata-rata dibandingkan ketiga aspek pembangun lainnya.

p. Untuk indikator Keadilan dan Keterbukaan, aspek yang perlu diperbaiki terutama dalam memperlihatkan pelayanan administratif, konsultasi, ataupun informasi kepada semua masyarakat yang memerlukan bantuan atau membutuhkan tenaga dan pikiran yang berkaitan dengan organisasi.

q. Untuk indikator Penguasan Iptek yang Diperlukan untuk Melaksanakan Tugas, aspek yang perlu diperbaiki adalah kemampuan untuk mengoperasionalkan mesin ketik dan/atau komputer, kemauan yang kuat untuk terus meningkatkan pengetahuan serta kemampuan dan sikap berpikir yang sistematis dan edukatif.

\section{Kota Banjar Baru (Kalimantan Selatan)}

Kota Banjar baru merupakan salah satu wilayah administrasi Provinsi Kalimantan Selatan. Dari persepsi responden yang ada terlihat bahwa ke-17 indikator budaya kerja telah diterapkan dengan "baik", beberapa indikator yang harus diperbaiki terutama Ketepatan (Keakurasian) dan kecepatan serta disiplin dan keteraturan kerja, Wewenang dan tanggung jawab, Kreativitas dan kepekaan terhadap Lingkungan Tugas, Integritas dan Profesionalitas, Keteguhan dan Ketegasan, Rasionalitas dan emosi, Disiplin dan keteraturan kerja. Adapun kondisi dari 17 prinsip budaya kerja dapat dilaporkan sebagai berikut:

a. Pada indikator Komitmen terhadap Visi Misi Organisasi, Tujuan, Kebijakan dan Perundang-undangan yang Berlaku, aspek yang perlu diperbaiki terutama dalam penetapan tujuan dan Rencana kerja yang dibuat oleh pimpinan untuk kurun waktu tertentu.

b. Untuk indikator Wewenang dan Tanggung Jawab , aspek yang perlu diperbaiki terutama dalam memberikan pelayanan kepada masyarakat para pegawai dalam lingkungan organisasi serta penggunaan barang dan jasa oleh pimpinan dan/atau setiap 
pegawai dalam memberikan pelayanan kepada masyarakat dan/atau dalam operaional kegitan internal organisasi.

c. Dalam indikator Keikhlasan dan Kejujuran, aspek yang perlu diperbaiki terutama dalam memberikan laporan kerja kepada atasan atau pimpinan serta keikhlasan dan kejujuran itu sendiri dalam menjalankan tugas dan wewenangnya.

d. Pada indikator Integritas dan Profesional, aspek yang perlu diperbaiki terutama kecakapan dan penguasaan terhadap bidang tugasnya serta hasil kerja yang produktif, berkualitas, efektif dan efisien perlu terus .

e. Indikator Kreativitas dan Kepekaan terhadap Lingkungan Tugas merupakan salah satu indikator yang paling lemah diantara 17 indikator lainnya, aspek yang perlu diperbaiki adalah kemampuan untuk mengetahui kelemahan dan kekuatan organisasi dan kemampuan antisipatif terhadap peluang dan hambatan, kemauan dan kemampuan untuk melakukan proses pembelajaran terhadap persoalan, kemajuan ilmu pengetahuan, dan teknologi serta isu-isu yang berkembang dalam masyarakat.

f. Dalam indikator Kepemimpinan dan Keteladanan, aspek yang perlu diperbaiki terutama teladan yang baik dalam kehadiran kerja, pekerjaan ataupun sikap dan perilaku serta kemampuan mendirikan dorongan atau suri teladan kerja kepada bawahan dan rekan kerja, bertindak tegas serta tidak memihak.

g. Pada indikator Kebersamaan dan Dinamika Kelompok/Organisasi, aspek yang perlu diperbaiki terutama kemampuan untuk menempatkan diri dan bekerja pada setiap situasi kerja di lingkungan organisasi.

h. Untuk Indikator Ketepatan (keakurasian) dan Kecepatan sebagai indikator yang terlemah, aspek yang harus diperbaiki adalah dalam melaksanakan tugas dan/atau pekerjaan secara terukur, tepat dan cepat, serta dalam bertindak atau melakukan tugas yang diberikan pimpinan atau rekan kerja dengan cepat dan tepat, disamping itu pemberian laporan tugas dan/atau pekerjaan secara cepat dan tepat waktu juga perlu mendapatkan perhatian yang serius.

i. Untuk indikator Rasionalitas dan Emosi, aspek yang perlu diperbaiki terutama kemampuan pegawai dalam mengoperasionalisasikan uraian tugas pokok organisasi dalam tindakan atau program/kegiatan yang nyata dan masuk akal. Disamping itu kemampuan membuat perencanaan yang matang, masuk akal dan aplikatif juga perlu mendapatkan perhatian serius.

j. Pada indikator Keteguhan dan Ketegasan., aspek yang perlu diperbaiki adalah dalam hal kepastian dalam bertindak terhadap tugas dan pekerjaan yang merupakan wewenang dan tanggung jawabnya.

k. Dalam indikator Disiplin dan Keteraturan Kerja, aspek yang perlu diperbaiki terutama tindakan yang mentaati peraturan perundang-undangan yang berlaku serta kebijakan internal organisasi. Disamping itu dalam kedisiplinan jam kerja dan sikap dan tindakan yang menunjukkan keteraturan dalam bekerja juga perlu mendapatkan perhatian.

1. Untuk indikator Keberanian dan Kearifan dalam Mengambil Keputusan/ Menangani Konflik, aspek yang perlu diperbaiki terutama pengelolaan terhadap konflik yang muncul dalam organisasi.

m. Pada indikator Dedikasi dan Loyalitas, aspek yang perlu diperbaiki terutama kemauan dan kemampuan untuk bekerja di luar jam kerja.

n. Dalam indikator Semangat dan Motivasi, aspek yang perlu diperbaiki terutama penerimaan tugas dan tanggung jawab yang giat dan bergairah sesuai dengan tugas pokok dari unitnya.

o. Pada indikator Ketekunan dan Kesabaran, aspek yang perlu diperbaiki terutama ketenangan hati dalam menghadapi berbagai persoalan internal organisasi.

p. Untuk indikator Keadilan dan Keterbukaan, aspek yang perlu diperbaiki terutama dalam pelayanan administratif, konsultasi, ataupun informasi kepada semua 
masyarakat yang memerlukan bantuan atau membutuhkan tenaga dan pikiran yang berkaitan dengan organisasi.

q. Untuk indikator Penguasan Iptek yang Diperlukan untuk Melaksanakan Tugas, pada umumnya responden menyatakan sudah sangat baik. akan tetapi perlu terus ditingkatkan terhadap kemampuan untuk mengoperasikan mesin ketik dan/ atau komputer serta kemauan untuk terus meningkatkan pengetahuan yang berkaitan dengan tugas dan pekerjaan.

\section{Penutup}

Hasil penelitian menggambarkan bahwa secara umum daerah belum menaruh perhatian yang memadai untuk memperkuat budaya kerja di lingkungannya masing-masing. Dari 4 (empat) daerah yang disurvey, baru Kabupaten Kutai Timur yang sudah punya Peraturan Daerah tentang implementasi budaya kerja untuk organisasi pemerintah daerah. Itupun masih lebih banyak bersifat "retorika" karena belum dapat berjalan dengan baik sesuai kaidah yang ada. Disamping itu, di seluruh daerah juga belum ditemui adanya kelompokkelompok budaya kerja (KBK) yang berfungsi untuk menunjang pelaksanaan tupoksi organisasi.

Belum optimalnya penerapan budaya kerja bagi organisasi perangkat daerah ini nampaknya bersumber dari beberapa kondisi, antara lain belum adanya pemahaman secara utuh diantara jajaran aparatur daerah mengenai esensi dan manfaat budaya kerja. Selain itu upaya sosialisasi dan diseminasi dari instansi Pusat tentang tahapan dan teknik penerapan budaya kerja juga belum terprogram secara sistematis.

Oleh karena prinsip-prinsip budaya kerja sebagaimana diatur dalam Keputusan Menpan No. 25/KEP/M.PAN/4/2002 belum terimplementasikan dengan baik, maka belum dapat diketahui sejauhmana pengaruh 17 variabel budaya kerja terhadap peningkatan kinerja pembangunan dan pemerintahan daerah. Hasil penelitian baru dapat mengidentifikasi komponen-komponen budaya kerja yang relatif sudah baik, serta komponen-komponen budaya kerja lainnya yang masih memerlukan peningkatan atau pembenahan. Meskipun demikian, penelitian ini merekomendasikan agar upaya peningkatan budaya kerja dilakukan secara komprehensif dengan penekanan pada variable/komponen tertentu. Upaya peningkatan praktek budaya kerja sendiri dapat ditempuh melalui pembentukan KBK untuk setiap SKPD (satuan kerja pemerintah daerah), pelatihan dan bimbingan teknis tentang aspek-aspek startegis budaya kerja, serta peningkatan pengawasan dan monitoring/evaluasi program dan kegiatan di setiap SKPD. Perlu adanya penerapan reward bagi yang berprestasi dan sanksi yang tegas bagi yang melanggar aturan, perlu adanya pelatihan dan bimtek tentang aspekaspek strategis budaya kerja, perlunya peningkatan pengawasan dan monitoring/evaluasi program dan kegiatan di setiap SKPD serta perlunya setiap Daerah merumuskan perda sebagai payung hukum untuk implemetasi 17 nilai dasar budaya kerja, sedangkan bagi daerah yang sudah memiliki perda agar lebih dioptimalkan lagi. 


\section{Referensi}

Tasmara, Toto, 2002, Membudayakan Etos Kerja Islami, Jakarta: Gema Insani Press.

Lembaga Administrasi Negara, 2004, Budaya Kerja Aparatur Pemerintah, laporan hasil penelitian, Jakarta

Nonaka, Ikujiro dan Hirotaka Takeuchi, 1995, The Knowledge-creating Company, How Japanese Companies Create the Dynamics of Innovation, Oxford University Press.

Osborne, David dan Peter Plastrik, 1996, Banishing Bureaucracy, The Five Strategies for Reinventing Government, Addison Wesley.

Osborne, David dan Ted Gaebler, 1992, Reinventing Government, How the Entrepreneurial Spirit Is Transforming the Public Sector, Addison Wesley.

Savas, E. S., 1987, Privatization: The Key to Better Government. Chatham, NJ: Chatham House.

Senge, Peter M., 1995, The Fifth Discipline, Bantam Doubleday Dell Publishing Group, Inc.

Utomo, Tri Widodo W., 2004, Pematangan Birokrat Muda Sebagai Faktor dan Aktor

Kunci Dalam Reformasi Birokrasi, makalah dalam rangka HUT LAN-RI Ke-47 dan HUT-

RI Ke-59, Bandung.

et.al., 2005. “Kajian Tentang Budaya Kerja Organisasi Pemerintah

Daerah di Kalimantan”, Samarinda: PKP2A III LAN.

World Bank, 1996, World Development Report: From Plan to Market, Oxford University Press.

TAP MPR No.VI/MPR/2001 tentang Etika Kehidupan Berbangsa memberi dasar pada

Pengejawantahan Etika dalam Proses Kehidupan Berbangsa dan Bernegara;

TAP MPR No. XI/MPR11998 tentang Penyelenggaraan Negara yang Bersih dan Bebas dari Korupsi, Kolusi, dan Nepotisme;

Undang-Undang No. 28 Tahun 1999 tentang Penyelenggaraan Negara yang Bersih dan Bebas dari Korupsi, Kolusi dan Nepotisme;

Undang-Undang No. 43 Tahun 1999 tentang Perubahan atas Undang-Undang No. 8 Tahun 1974 tentang Pokok-Pokok Kepegawaian;

Undang-Undang No. 20 Tahun 2001 tentang Perubahan atas Undang-Undang No. 31 Tahun 1999 tentang Pemberantasan Tindak Pidana Korupsi; 
Undang-Undang No. 30 Tahun 2002 tentang Komisi Pemberantasan Tindak Pidana Korupsi;

Peraturan Pemerintah No. 30 Tahun 1980 tentang Peraturan Disiplin Pegawai Negeri Sipil;

Keputusan Menteri Negara Pendayagunaan Aparatur Negara No.125/1990 tentang Susunan Keanggotaan Tim Inventarisasi Persiapan Pelaksanaan Budaya Kerja;

Keputusan Menteri Negara Pendayagunaan Aparatur Negara NO. 04/1991 tentang Pedoman Pemasyarakatan Budaya Kerja;

Keputusan Kementerian Pendayagunaan Aparatur Negara No.25/KEP/M.PAN/4/ 2002 tentang Pedoman Pengembangan Budaya Kerja Aparatur Negara;

Keputusan Kementerian Pendayagunaan Aparatur Negara No. 63l KEP/M.PAN/7/ 2003 tentang Pedoman Umum Penyelenggaraan Pelayanan Publik. 